\title{
Anmeldelse av bind 2 av Dansk Sproghistorie: Ord for ord for ord.
}

Utgitt av Det Danske Sprog- og Litteraturselskab. Hovedredaktør Ebba Hjorth.

\section{AGNETE NESSE}

\section{TITTEL, YTRE RAMMER OG NETTSIDE}

Min første innskytelse da jeg fikk dette bindet $\mathrm{i}$ hende, var om tittelen Ord for ord for ord var ment som en spøk, eller om det var en slags ordlek som jeg som ikke-dansk var avskåret fra å forstå. Men slik er det ikke. I forordet forklares tittelen med at "bindet mest af alt handler om sprogets byggesten, ordene. Bogen behandler med ord det danske sprog ord for ord." Som lesere av dette bindet skal vi altså være forberedt på å gå til språkhistorien på ordnivå, mens de andre bindene tar seg av tekstnivået, skriftnivået og det grammatiske nivået.

Fra første side av giøres det tydelig at Ord for ord for ord er en del av et større verk. Allerede før første side faktisk, siden både innsiden av permen og bokens aller første side er brukt til en presentasjon av verket Dansk Sproghistorie. Dette språkhistorieprosjektet skal, når det er ferdig, inneholde 6 bind med $\mathrm{i}$ alt 21 kapitler. Så langt er bind 1 og 2 kommet ut. Kapitlene i Dansk Sproghistorie er nummerert ut fra plassering i verket, ikke ut fra plassering i det enkelte bindet. Bind 1 inneholder kapittel 1-4 og bind 2, som denne anmeldelsen tar for seg, inneholder kapittel 5-9. Kapitlene er delt inn i underkapitler, skrevet av ulike forfattere. I bind 2 bidrar $i$ alt 23 forfattere, 12 kvinner og 11 menn. På bakre perm, og på bokens to aller siste sider, presenteres lydskriften som brukes $\mathrm{i}$ verket, $i$ tillegg til forkortelser som er relevante for hele verket. Leseren blir presentert for både den tradisjonelle, danske lydskriften Dania, og den internasjonale IPA-lydskriften. Måten permene og de første og siste sidene er brukt på, gir signal om at ytterverket til boken tilhører hele verket, og fremhever verksfølelsen en har når en leser dette bindet.

I tillegg til de planlagte seks bindene med fysiske bøker, har Det 
Danske Sprog- og Litteraturselskab, og redaksjonen, satset tungt på et nett-tillegg som en finner på nettadressen (dansksproghistorie.dk). På disse nettsidene finner en detaljerte referanselister, utfyllende artikler, lyd- og filmklipp. I papirboken er det lagt inn ikoner i margen de stedene der papirbokens tekst passer særlig godt sammen med et bestemt sted i nett-tillegget. For eksempel oppfordres leseren på s. 205, i underkapittel 7.4 "Udtalen i Yngre nydansk" (skrevet av Lars Brink og Jørn Lund), å skru på sin pc eller slå på sin telefon, finne frem til rett kapittel på nettsiden og så høre skuespilleren Poul Reumert deklamere Adam Oehlenschlägers dikt "Guldhornene" (1802) i en innspilling fra 1954, ledsaget av J.P.E. Hartmanns (1805-1900) orkesterverk Guldhornene (1832). Det kan virke noe omstendelig å skulle bevege seg til en annen plattform midt i lesningen, men det er verdt de sekundene eller minuttene det tar. Tilsvarende henvises en i underkapittel 9.6 "Nyere indvandrersprog" (skrevet av Pia Quist) til nett-tillegget for å se på utdrag fra Danmark Radios Yallabrup Fargeby. Avstanden mellom Poul Reumerts deklamasjon og språket til deltagerne i Yallahrup Færgeby er knyttet til stil og sjanger; men også til tid, og denne avstanden blir enda tydeligere når en hører den enn når en bare leser om den. Som norsk leser smigres en over at norske og svenske ordtoner også er tatt med i nett-tillegget, og at en, når en i nett-tillegget leser om Dansk Sprognævns nyordsliste fra 2016, blir sendt videre via lenker til tilsvarende svenske og norske nyordslister.

Jeg må innrømme at jeg opplever valget om å satse så stort og bredt på et nett-tillegg til papirbøkene som dristig optimisme. Når ikonene først står der i margen på bøkene og det også i selve brødteksten hyppig henvises til alt det flotte ekstrastoffet en kan finne på nettsiden, så fanger bordet. For at dette skal være vellykket er Det Danske Sprogog Litteraturselskab avhengig av at noen opprettholder nettsiden de neste femti år - eller hvor lenge det nå er til en ny språkhistorie blir skrevet.

\section{STRUKTUR OG FORM}

Dansk Sproghistorie er ikke en kronologisk oppbygget språkhistorie, slik for eksempel Peter Skautrups enmannsverk Det danske sprogs historie I-IV (1944-1968) er strukturert, og slik det har vært vanlig i nor- 
ske språkhistorier, særlig til undervisningsbruk. Heller har en valgt en tematisk oppbygget fremstilling, der en må ned på kapittelnivå - og noen ganger på underkapittelnivå - for å få en kronologisk oversikt. Periodene det opereres med i Dansk Sproghistorie er Runetiden (ca. 1501100), Gammeldansk (ca. 1100-1500), Ældre nydansk (ca. 1500-1700) og Yngre nydansk (ca. 1700-i dag.). I bind 2 er det altså slik at vi innenfor de temaene bindet omhandler, som er ortografi, tegnsetning, uttale, ordforråd og ord fra andre språk, går gjennom disse språkhistoriske periodene kronologisk. Men noe variasjon er der: For eksempel er kapittelet om tegnsetning bare delt i to, før og etter 1500, mens kapitlene om ortografi og uttale er delt i fire.

En temabasert fremstilling av språkhistorien gir muligheten for å trekke selve det språkvitenskapelige i forgrunnen, mens en rent kronologisk fremstilling i større grad inviterer til et helhetlig syn, der politisk historie, kulturhistorie, religiøs historie og de ulike språklige nivåene veves inn i hverandre. Skautrups språkhistorie gir et godt eksempel på et slikt opplegg. Den fremste ulempen ved en temabasert fremstilling av språkhistorien er at en risikerer en del overlappinger mellom de ulike kapitlene. Særlig vanskelig å unngå dette er det når to tema vanskelig kan skilles fra hverandre. I bind 2 er dette først og fremst et problem mellom kapittel 5.1 om ortografi i runetiden og kapittel 7.1 om uttale i runetiden. Selv om det er de samme forfatterne som står bak begge kapitlene, nemlig Michael Lerche Nielsen og Marie Stoklund, så oppleves kapitlene som så pass like at en sammenslåing kunne vært å foretrekke. Det står jo også på s. 12 at "I praksis er det [...] vanskelig at holde runeortografi og udtaleforhold ude fra hinanden." Vi vet jo ingenting om uttalen i runetiden som ikke kommer fra ortografien, og selv om det i teorien kan være nyttig å prøve å tvinge de to nivåene fra hverandre, så fungerer det ikke optimalt her. Det gjelder også i kapittel 7.3 om uttalen i eldre nydansk, her kunne en vunnet en del på å diskutere ortografi og fonologi samlet, selv om dette ville markert et brudd med den strenge strukturen som tilsier at hvert tema skal presenteres for seg.

Stort sett fremstår den strenge strukturen som oversiktlig og grei. Det er gjort et godt arbeid fra redaksjonens side for å få selve fremstillingsformen jevn gjennom hele boken. Dette er ikke et verk som først og fremst er skrevet for fagfolk; men for det vi i Norge ofte henviser 
til som "den opplyste allmennheten." Likevel unngår forfatterne den forenklingen en ofte finner i mer populære fremstillinger. I kapittel 5.1 må en særlig berømme forfatterne Michael Lerche Nielsen og Marie Stoklund for at de, for eksempel i presentasjonen av overgangen fra 24 til 16 runer i fuparken, på en svært pedagogisk måte viser flertydigheten som oppsto som en konsekvens av sammenslåingen av runetegn. På samme pedagogiske, men likevel nyanserte måte ses enkeltinnskrifter i sammenheng med hverandre. Det er også positivt at ulike tolkningsmuligheter blir presentert, slik som på s. 21 der det skrives om Hørninge-stenen.

Boken er prydet av fine bilder og illustrasjoner. Etter min smak er bilde- og illustrasjonstekstene som oftest litt for lange. Det kan være en smaksak: Noen mener at bildetekster som gir ny informasjon er på sin plass. Selv foretrekker jeg at ny informasjon er plassert i brødteksten fordi jeg da får bedre flyt i lesningen. Tabellene, som der er mange av i denne boken, er for det meste selvforklarende og greie tillegg til brødteksten. Men noen ganger, som med tabell 4 på s. 67, er verken tabellen eller tabellteksten informerende nok, og det blir ikke klart hva som egentlig er forskjellen mellom "dominerende variant" og "foretrukken variant."

\section{KAPITTEL 5 ORTOGRAFI (84 SIDER)}

Tidsbestemmelse av runeinnskrifter er ikke en så eksakt vitenskap som vi kanskje kunne ønske oss, og jeg regner med at det er derfor tidsangivelsen så mange steder mangler ved omtale av runeinnskrifter. Det oppleves likevel som et savn at tidsangivelse ikke antydes. Om en ikke trenger å vite akkurat når en innskrift er blitt til (det er jo ofte umulig), vil det være en god ledesnor for leseren å i det minste vite hvordan forskerne antar at den relative kronologien mellom innskriftene er.

Mens kapittelet om runetidens ortografi er holdt i en lett, fortellende prosa, er det tilsvarende kapittelet om ortografien i gammeldansk (skrevet av Britta Olrik Frederiksen) mer oppramsende, og deler av dette kapittelet egner seg nok best som oppslagsverk. Det er et pedagogisk godt grep at "Særlig vigtige fagord og tegn" blir presentert i begynnelsen av kapittelet, på s. 27. Mindre heldig er det at ordeksemplene ikke oversettes fortløpende til moderne dansk. Selv om mange av disse 
ordene oversettes i skjemaer, ville det vært en fordel å få oversettelsen samtidig som ordformen. På sidene 42 og 43 er der et flott oppslag der en tekst vises både $\mathrm{i}$ faksimile av håndskriftet, $\mathrm{i}$ transkripsjon og oversettelse.

På sidene 46 og 47 vektlegges hvordan ortografisk variasjon er knyttet til teksttype. Her ville jeg i tillegg ventet en diskusjon om denne ortografiske variasjonen også kunne være knyttet til geografi og dialekt, men det finner en kanskje igjen $i$ et annet kapittel $i$ et annet bind. Vi mister sammenheng mellom ortografi og geografiske forhold i dette temabaserte verket, men vinner en konsentrasjon om ortografien. Dette innebærer blant annet at forfatterne får bedre plass til det rent grafiske, som bruk av dobbelskrivning ved ulike typer s'er (s. 45) og kapittelets gode avslutning om "Store bogstaver, ordadskillelse og orddeling ved linjeskifte." Dette er emner som lett kan forsvinne når ortografi knyttes for tett mot fonologi, slik vi i hvert fall har en tradisjon for i norsk språkhistorieskrivning.

Vektleggingen av språkets grafiske sider finner vi også i kapittel 5.3 "Ortografien i Ældre nydansk" (skrevet av Hanne Ruus). På s. 59 finner vi flotte illustrasjoner av bokstaver, med forklaring. Her gjøres ellers noen grep for å hindre altfor mye oppramsing, for eksempel en noe grundigere gjennomgang av noen av eksemplene på s. 65. Kapittel 5.3 avsluttes med det viktige faktum at trykknormen gikk foran håndskriftnormen, eller sagt på en annen måte - de profesjonelle skriverne ledet an i den ortografiske utviklingen.

Kapittel 5.4 "Ortografien i Yngre nydansk" (skrevet av Henrik Galberg Jacobsen) begynner med en innledning som til fulle viser hvor komplekst Dansk Sproghistorie er. Leseren blir henvist til en lang rekke andre kapitler i verket, mange av dem ennå ikke skrevet. I dette kapittelet er det også en lang rekke henvisninger til nett-tillegget, og til sammen gir disse stadige henvisningene et noe utilfredsstillende inntrykk. Denne leseren ble i hvert fall sittende med en opplevelse av at selv om jeg leser dette underkapittelet med glede, er det på langt nær godt nok, for der finnes så mye mer der ute som en også bør lese. Men kapittelet står ellers godt i seg selv, ved sine mange interessante diskusjoner. Fra norsk ståsted er det tydelig at de forandringene i det felles skriftspråket som fant sted i løpet av 1700-tallet, gjorde skriftspråket mer fremmed 
for norsk talespråk, og sånn sett kanskje beredte grunnen for den delingen mellom dansk og norsk som ble iverksatt i løpet av siste halvdel av 1800-tallet. Ellers har forfatteren overbevist meg om at kryssord har sin naturlige plass i en språkhistorisk fremstilling, og at kryssordene har hatt stor betydning for folks bevissthet rundt hvordan ord skal skrives og bøyes.

\section{KAPITTEL 6 TEGNSÆTNING (31 SIDER)}

Det relativt korte kapittelet om tegnsetning er som nevnt delt inn i bare to underkapitler. Perioden frem til 1500 er satt sammen til ett underkapittel (skrevet av Ebba Hjorth), mens perioden etter 1500 likeledes er samlet (skrevet av Henrik Galberg Jacobsen). Den eldste perioden byr ikke på så mange eksempler på tegnsetning, men forfatteren får fint frem hvordan runeristere $i$ olddansk periode bedrev (ubevisst) syntaktisk analyse ved å sette skilletegn mellom setningsledd. Faksimiler med påtegnete sirkler og piler brukes her og flere andre steder for å illustrere ortografi og tegnsetning på en svært oversiktlig måte. Om tiden etter 1500 er der adskillig mer å si, både når det gjelder bruken av skråstrekskomma og innføring av spørsmålstegn, og ikke minst når vi kommer til den nyere tid med diskusjonene rundt kommatering - pås. 127 brukes endatil begrepet kommakrig!

\section{KAPITTEL 7 UDTALE (121 SIDER)}

Dette kapittelet tar for seg uttalen gjennom de fire språkhistoriske periodene, og mens underkapittel $7.1 \mathrm{om}$ runetiden inneholder en del repetisjon både fra kapittel 5 om ortografi og noe fra kapittel 6 om tegnsetning i runetiden, så får vi i delen som heter "Vejen frem mod fællesnordisk" en god gjennomgang av synkope, omlyd, brytning og assimilasjoner. Begrepet fallesnordisk forklares på s. 147 som 'yngre urnordisk', altså vikingtidens språk.

7.2 "Udtale i Gammeldansk" (skrevet av Britta Olrik Frederiksen) innledes av en introduksjon om uttalehypoteser basert på en sammenstilling av skriftlige kilder og nyere uttaleformer. Slutten av dette kapittelet inneholder så et viktig spørsmål: "Hvorfor - tilpasning til omgivelserne?" Svaret gir indrelingvistiske forklaringer knyttet til artikulasjon og energi mest kraft, mens en henvisning til den amerikanske 
språkhistorikeren H.H. Hocks snart 30 år gamle utsagn om at "de fleste 'post mortem'-forsøg på at udrede mulige sociale - og så sikkert i endnu højere grad psykologiske - årsager til sprogændringer har vist sig frugtesløse" parkerer snart tre tiår med forskning innenfor historisk sosiolingvistikk som, siden Suzanne Romaines studie i 1982, nettopp viser det fruktbare i å nærme seg språkhistorien ved hjelp av sosiolingvistiske metoder (se for eksempel Hernández-Campoy \& Conde-Silvestre 2012 og en gjennomgang av språkhistoriske innfallsvinkler i Nesse 2018). Jeg håper at bind 3 i Dansk Sproghistorie, som inkluderer kapitler om både dialekter og sosiolekter, er mer åpen for sosiale forklaringsmodeller.

7.3 "Ældre nydansk" (skrevet av Simon Skovgaard Boeck) begynner med å presentere en inndeling i mindre vante skrivere på den ene siden, og lærde skrivere på den andre. Særlig interessant blir dette når hovedeksemplet på en uvant skriver er selveste kongen - Frederik 2 (15431588). Eksemplene fra hans tekst viser også at det ikke nødvendigvis er slik at mindre vante skrivere skriver uttalenært, like ofte er tekstene deres preget av manglende forståelse for korrespondansene (eller de manglende korrespondansene) mellom tale og skrift (utdypes også $\mathrm{i}$ Nesse 2018: 367-369). Av særlig interesse er gjennomgangen av palataliseringen av $l l$ og $n n$ og hvordan det palatale innslaget ble realisert ved hjelp av henholdsvis $l d$ og $n d$ i skrift, og at denne skrivemåten besto også etter depalataliseringen av talemålet. I norsk skriftspråkshistorie har fjerningen av disse palatal-d'ene vært en viktig del av den såkalte fornorskingen av norsk skriftspråk, selv om svært mange norske dialekter faktisk har palatalisering av $l l$ og $n n$ den dag i dag.

7.4 "Yngre nydansk" (skrevet at Lars Brink og Jørn Lund) innledes av et fugleperspektiv over perioden, og forfatterne slår fast at det er mindre variasjon i det danske talemålet $\mathrm{i}$ dag enn det var på begynnelsen av 1700-tallet. Videre beskrives Københavns status som hele rikets språklige normsenter, og det typiske for slike normsentre - at de er både innovative og konservative på en gang - blir forklart. Når det gjelder grunnleggende fonologiske forandringer, er særlig skarre-r / В/ verdt å nevne, som et eksempel på et språktrekk som først kom til København, så kanskje hundre år senere til dialektene rundt $i$ landet. I 7.4 er der valgt en annen måte å fargelegge teksten på enn i de andre kapitlene: Hver gang et nytt språktrekk introduseres, kommer først et 
farget avsnitt med hovedpunktene, før resten av utlegningen kommer uten farge. For denne leseren virket ikke dette spesielt godt.

Selv om det er mange såkalte lydlover, altså systematiske forandringer på lydnivå, som gjennomgås i kapittel 7, er det, særlig i yngre nydansk, slik at mange av disse lydovergangene slett ikke er "lydlover" men leksikaliserte forandringer. Dette reflekteres i fremstillingen som preges av oppramsinger av ord som har fått eller ikke fått den aktuelle lydforandringen.

7.5 "Stød, tryk og tonegang” (skrevet av Lars Brink) byr på mye som er komplisert for en støt-løs leser, men fremstillingen er overveiende slik at en kan forstå det lingvistiske uten å beherske støt-systemet. På s. 235 er Einar Haugens kart over ordtoner og støt i Skandinavia gjengitt. Dessverre mangler den nordligste delen av Norge, som i aller høyeste grad er relevant, i og med at mesteparten av Nord-Troms og Finnmark mangler tonemopposisjon. Underkapittelet om støt, trykk og tonegang har i større grad enn de andre kapitlene en faghistorisk gjennomgang av utforskningen av emnet, noe som i og for seg er interessant lesning, i hvert fall for en språkhistoriker.

\section{KAPITTEL 8 ORDFORRÅD (123 SIDER)}

Det første underkapittelet "Arveord, låneord og fremmedord" (skrevet av Eva Skafte Jensen) begynner med en fin introduksjon - og ikke minst problematisering - om hva som ligger i de tre begrepene i tittelen. Videre diskuteres hvilke kriterier som brukes for å hevde at et ord ikke er integrert i dansk. Dette kapittelet er preget av en positiv, anti-puristisk holdning til ordforrådet, for eksempel står det på s. 264 at dansk ble "beriget" av ord fra middelnedertysk. En skjønnhetsfeil i referansene er at det to steder, på s. 262 og i referanselisten på s. 482, står at den norske norrøntfilologen Odd Einar Haugen (f. 1954) står bak amerikaneren Einar Haugens artikkel "The analysis of linguistic borrowing" fra 1950.

Etter innføringen i ordtyper kommer Bent Jørgensens underkapittel 8.2 om orddannelse. Selv om deler av dette kapittelet, særlig fra s. 287 av, fremstår som en generell innføring i morfologisk analyse mer enn språkhistorie i snever forstand, er her mye genuint historisk å lese. Og å undre seg over, for eksempel dette at dansk ikke har, og ikke har 
hatt, et aktivt diminutivssuffiks tilsvarende tysk -chen eller -lein. Noen steder savner jeg at forfatteren prøver å forklare hva som har skjedd når ord har forandret betydning, for eksempel står det på s. 273 at både killing og kalling "misvisende" har endret betydning. Her kunne både teorier om semantisk forskyvning og sosiolingvistiske teorier om språk og kjønn vært til hjelp for å forklare det "misvisende". På s. 275 og 276 er der viet en egen del til "Kvinderne", så en henvisning hit fra s. 273 der kalling nevnes, kunne vært en fin service for leseren. Kjønn nevnes også på s. 288, men oppstillingen av ordene forkvinde, talskvinde, tillidskvinde og karrierekvinde halter, fordi de tre første eksemplene er avledet fra tilsvarende ord på -mann (formann, talsmann, tillitsmann), mens det siste ordet er et ikke likestilt ord - ingen ville kalle en mann for en karrieremann, siden det har vært en selvfølge at en mann har et yrke. I dag vil jeg påstå at det er et godt tegn på økt likestilling at ordet karrierekvinne (i hvert fall i norsk) er - om ikke utdødd, så i hvert fall sjelden å se eller høre.

Etter 8.1 og 8.2 er vi tilbake på det kronologiske sporet, og får tre underkapitler om henholdsvis "Runedansk og gammeldansk" (skrevet av Marita Akhøj Nielsen), "Ældre nydansk" (skrevet av Simon Skovgaard Boeck) og "Yngre nydansk" (skrevet av Henrik Andersson). På s. 297 brukes "et specialiseret samfund" som forklaring for at danske språkbrukere lånte inn ord fra middelnedertysk og fra latin via middelnedertysk. Her savner jeg noen perspektiv på makt og dertil hørende språklig dominans som en utfyllende begrunnelse.

8.4 "Ældre nydansk" begynner med en oversikt over de tidligste ordbøkene, og en betraktning over at "Udforskningen af ældre dansk har da også hovedsagligt begrænset sig til middelalderens gammeldanske sprog, mens det ældre nydanske sprog ligger i delvist forskningsmørke" (s. 305). Heldigvis tvinger den stramme strukturen i Dansk Sproghistorie frem en rik dekning av eldre nydansk periode, en periode som også er svært relevant å kjenne til for norske språkhistorikere, siden skriftspråket og offentligheten var felles i den perioden. Av alle de små og store eksempler som brukes for å illustrere språket i denne perioden, synes jeg det om ormen og slangen (s. 310) kan nevnes spesielt, fordi det også viser viktigheten av de valgene oversettere, i dette tilfellet av Bibelen, har gjort gjennom tidene. 
I 8.5 "Yngre nydansk" har fenomenet purisme en sentral plass, og det faktum at selv om det veksler gjennom tidene hvilket språk man retter purismen mot, så ser det ut til at purisme som fenomen er seiglivet. I den yngre nydanske perioden er det først og fremst nabospråket tysk purismen rettes mot, først etter midten av det 20. århundret tar purismen mot engelsk over. På s. 336 presenteres en liste over bøker og artikler om nye ord. Denne kunne med fordel blitt henvist til nett-tillegget, siden oppramsing av titler ikke fungerer så godt som en del av den språkhistoriske teksten.

Etter de tre kronologiske underkapitlene, kommer 8.6 "Fagsprog" (skrevet av Anne Duekilde), 8.7 "Slang" (skrevet av Peter Stray Jørgensen) og 8.8 "Navne" (skrevet av Vibeke Dalberg). Underkapittelet om fagspråk er ikke satt opp kronologisk, men noe kronologi er lagt inn også her, for eksempel i en fin tekstboks på s. 341 der fagbegrep er knyttet til det punkt i språkhistorien hvor begrepene først dukker opp i kildematerialet. Underkapittelet om slang presenterer en viktig kilde, trolig ikke bare for slang, men også andre språklige fenomen: skolekomediene, altså teaterforestillinger som kan dateres helt tilbake til senmiddelalderen. De begynte som religiøse, didaktiske stykker, men "efterhånden afløstes det af mere verdslige emner og temaer med ofte ret platte og dagligdagse vendinger" - og altså slang. At det å skrive om ulike slanguttrykk ikke er like enkelt i dag heller, ser en av ordforklaringene til enkelte slanguttrykk på s. 358 og 359. Der fisk forklares ved 'kvindelige kønsdele', forklares både stilk, stjart og svans enkelt og greit med 'penis', ikke med 'mandlige kønsdele'. Dette stemmer godt med det som står på s. 366 om at Politikens innsamling av slangord omkring 1980 viste at selv om der ikke var mulig å finne viktige forskjeller med hensyn til sosial klasse eller geografi, så var der forskjeller når en dro inn kjønnsdimensjonen. Heller ikke språkhistoriske forfattere går klar her.

Underkapittelet om navn gir også en elementær innføring i hva fenomenet navn er før det historiske presenteres. Flere av kapitlene i denne boken innledes på denne måten; det er et valg som nok kan diskuteres, men som gjør Dansk Sproghistorie egnet til undervisningsformål. Og det vil i neste omgang bety flere lesere. Videre i 8.8 kommer en del om datering av navn, og litt om oppkallingsskikker. Fra s. 376 er der en 
svært interessant del om lovgivning knyttet til navn, for eksempel dette at man i 1904 ble oppfordret til å lage nye navn for å erstatte -sen-navnene.

\section{KAPITTEL 9 ORD FRA ANDRE SPROG (84 SIDER)}

Det siste kapittelet i Ord for ord for ord er viet ord fra andre språk, med underkapitler om gresk og latin, tysk, romanske språk, engelsk, nordiske språk og nyere innvandrerspråk. 9.1 "Græsk og latin" (skrevet av Johnny Christensen og Niels Grotum Sørensen) byr på et interessant helhetsperspektiv når det gjelder latin: At det ikke bare er de latinske lånordene som har preget de europeiske språkene, men at også orddanningsmåter (og jeg vil gjerne legge til - mye av tekstkulturen vår) er preget av latin på en slik måte at "det ligger som et fælles, samlende substrat under dem alle." (s. 388). Også fremstillingen av en filosofisk begrunnelse for purisme og arbeidet for folkespråk gir mening ut over den perioden det fortelles om.

9.2 "Tysk" (skrevet av Vibeke Winge) dekker både den nedertyske og den høytyske innflytelsen. Et viktig poeng er at siden nedertysk ligner mer på dansk enn det høytysk gjør, delvis på grunn av den høytyske lydforskyvning, så er det ikke like lett å se at de nedertyske ordene faktisk er lånord. Skjemaene på s. 402 og 403 har muligens dette for øye, jeg leser dem som et ønske om å vise likhetene mellom dansk og nedertysk på den ene siden, og forskjellene overfor høytysk på den andre. Det er mulig at det er viktig å bruke plass på dette, siden det for mange, (hvis det er slik i Danmark som det er i Norge), er helt ukjent hva for et slags språk nedertysk var (er). Ellers synes jeg det fungerer fint at lånordene er gruppert etter samfunnsdomene. Winge drar også inn det helt siste i utviklingen, der tysk eller tysklignende ord og bokstaver har fătt en slags renessanse i deler av kulturlivet. Dette er noe som også kjennes i Norge. På s. 438 nevnes det, i underkapittelet om engelsk, at "den nye tysken" faktisk i stor grad kommer til Skandinavia via amerikansk!

9.3 "Romanske sprog" (skrevet av Henrik Lorentzen) forteller oss at fransk ble et motespråk, men ikke hvorfor. Det brukes uttrykk som snobberi, men det oppleves ikke som noen fullgod forklaring. Derimot fungerer sammenligningen på s. 423 mellom skrivemåtene av franske lånord i de tre skandinaviske språkene fint, og diskusjonen rundt tilpas- 
ning til dansk bøyning er viktig. 9.4 "Engelsk" (skrevet av Pia Jarvad) begynner dessverre med en repetisjon av det som står helt fremst $\mathrm{i}$ kapittel 8, så her kunne en med fordel kortet litt ned. Tredelingen av engelsk i britisk, amerikansk og global engelsk er en viktig presisering. Årstall for innføring av ord er presentert fint i bildeteksten på s. 436, men utover det er det litt for mange oppramsinger av engelske lånord uten at vi får vite om det er snakk om eldre eller nyere lån. Når det gjelder det å godta danske avløsningsord er det slik at fagfolk følger etter vanlige folk, slik at spontane avløsningsord blir vanligere. Dette er en interessant kontrast til Norge, der det nok oftere har vært slik at de mange gode avløsningsordene som lages, får lite gjennomslag $i$ faktisk bruk.

9.5 "Nordiske sprog" (skrevet av Else Bojsen) viser noe av det samme som med nedertysk, at det kan være vanskelig å vite om et aktuelt ord er lån eller har felles opprinnelse. Videre får vi en påminnelse om hvor viktig kulturelle fenomen er og har vært for lån av ord mellom språk: Her nevnes religion (Birgittinerordenen), skiturisme, eventyr og sangtekster - og jeg tar meg $\mathrm{i} a ̊$ savne det aller nyeste, for eksempel fellesproduksjoner for TV som "Broen". Fremstillingen i 9.5 om den såkalte skandinavismen midt på 1800-tallet legger vekt på at deltagerne var redde for at den gjensidige forståelsen innad i Skandinavia skulle bli borte. I den forbindelse er jo de nye samproduksjonene for TV, der skuespillerne snakker eget språk, et tegn på at det så langt har gått bra med den gjensidige forståelsen. Til slutt må det sies at 9.5 kunne vært ryddet noe opp i; eksempler som gravlaks og hasselbackeartoffel gjentas flere ganger enn det er behov for.

Det aller siste underkapittelet er 9.6 "Nyere indvandrersprog" (skrevet av Pia Quist), og selv om bruken av og påvirkningen fra asiatiske og afrikanske språk er et relativt nytt fenomen i Danmark, så lover første overskrift "Indvandrersprog siden 1960'erne" godt for en språkhistorisk fremstilling. Dessverre blir det med denne overskriften, og det historiske perspektivet er ikke til stede i resten av underkapittelet. 9.6 er likevel en fin gjennomgang av viktige sider ved hvordan de aktuelle språkene preger dansk i vår tid. 


\section{OPPSUMMERING}

Alt $\mathrm{i}$ alt har det vært en stor glede å lese bind 2 av Dansk Sproghistorie, og mest av alt er jeg imponert over hvordan mine danske kollegaer evner å kombinere det faglig solide med en fremstillingsform som gjør at flere enn den snevre krets av språklig utdannete kan lese den med utbytte. Som det går frem av teksten over, er det særlig de sosiolingvistiske perspektivene jeg savner der forfatterne henfaller til karakteristikker som "snobberi" og andre folkelige forklaringsmetoder for språkforandring. En del repetisjoner finnes også mellom de ulike delene, men alt $\mathrm{i}$ alt er det så lite at det ikke ødelegger inntrykket av en bok som er godt disponert, velskrevet og informativ. Jeg krysser fingrene for at samspillet mellom papirverk og nettsider vil fungere etter planen i mange år fremover, og at resten av verket blir like vellykket som dette bindet.

Agnete Nesse, professor

Institutt for lingvistiske, litterære og estetiske studier

Universitetet i Bergen

Agnete.Nesse@uib.no

\section{LITTERATUR}

Haugen, E. 1950. The analysis of linguistic borrowing. Language 26. 210-231. DOI: 10.2307/410058. https://www.jstor.org/stable/410058

Hock, H.H. 1991. Principles of historical linguistics. Berlin: Mouton de Gruyter.

Hernández-Campoy, J.M. \& J.C. Conde-Silvestre. 2012. The handbook of historical sociolinguistics. Oxford: Wiley-Blackwell.

Nesse, A. (red.). 2018. Tidslinjer, bind 4 i H. Sandøy \& A. Nesse (red.), Norsk språkbistorie. Oslo: Novus.

Romaine, S. 1982. Socio-historical linguistics: Its status and methodology. Cambridge: Cambridge University Press.

Sandøy, H. \& A. Nesse (red.). 2016-2018. Norsk språkhistorie, bind 1-4. Oslo: Novus.

Skautrup, P. 1944-1968. Det danske sprogs historie, bind 1-4. København: Gyldendal. 